\title{
Phosphinite Thioglycosides Derived from Natural D-Sugars as Useful P/S Ligands for the Synthesis of Both Enantiomers in Palladium-Catalyzed Asymmetric Substitution
}

\author{
Noureddine Khiar, ${ }^{* a}$ Belén Suárez, ${ }^{\mathrm{a}}$ Victoria Valdivia, ${ }^{\mathrm{b}}$ Inmaculada Fernández*b \\ a Instituto de Investigaciones Químicas, C.S.I.C-Universidad de Sevilla, c/. Américo Vespucio 49, Isla de la Cartuja, 41092 Sevilla, Spain \\ Fax +34(95)4460565; E-mail: khiar@iiq.csic.es \\ b Departamento de Química Orgánica y Farmacéutica, Facultad de Farmacia, Universidad de Sevilla, c/ Profesor García González 2, \\ 41012 Sevilla, Spain \\ E-mail: inmaff@us.es
}

Received 18 July 2005

\begin{abstract}
Phosphinite thioglycosides I for which a modular synthetic approach is reported, were found highly efficient catalyst precursors for palladium(0)-catalyzed asymmetric substitution. Both enantiomers of the allylated products have been obtained with high ee (up to $96 \%$ ) using natural sugars as catalyst precursors.
\end{abstract}

Key words: P/S ligands, carbohydrates, both enantiomers, allylic substitution

The difficulty to predict the structural requirements of a ligand for acting as a successful catalyst explains the enduring need to develop new ligands which combine efficiency, wide scope and easy synthesis. ${ }^{1}$ Therefore, modular synthetic designs allowing a rapid optimization of the ligand structure for a high activity and/or selectivity in a precise chemical transformation are greatly desirable. Carbohydrates, which are amongst the cheapest and most abundant chiral starting materials, hold a range of structural characteristics that make them very appealing for such venture. ${ }^{2}$ Notably, carbohydrates possess various hydroxyl groups in different orientations, allowing easy tuning of steric, electronic and three-dimensional structure of carbohydrate based ligands. ${ }^{3}$ Conceptually, the utilization of carbohydrates in asymmetric synthesis is severely limited when both enantiomers are needed, as Lsugars are exceedingly expensive. While this problem has been elegantly solved by RajanBabu ${ }^{4}$ in the case of homodonor P/P ligands, up to now there is no solution in the case of mixed ligands with two different heteroatoms.
Following the seminal work of Evans, ${ }^{5}$ in this communication we report the first synthesis of mixed P/S ligands I derived from carbohydrates (Scheme 1), and their preliminary applications in a highly enantioselective palladium(0)-catalyzed allylic substitution. In our approximation both enantiomers of the allylated products have been obtained using pseudo-enantiomeric natural sugars as catalyst precursors. ${ }^{6}$

A fundamental characteristic of the phosphinite thioglycoside $\mathbf{I}$ is that upon coordination to the metal the anomeric sulfur atom becomes stereogenic. The close proximity of the chiral sulfur atom to the coordination sphere of the transition metal anticipates a good enantioselective discrimination in the catalytic process, provided that the low inversion barrier of the sulfur metal bond can be surmounted. ${ }^{5,7} \mathrm{We}$ have recently reported the preparation of $\mathrm{C}_{2}$-symmetric bis-thioglycosides as new homodonor $\mathrm{S} / \mathrm{S}$ ligands in $\mathrm{Pd}(0)$-catalyzed allylic alkylation of 1,3-diphenylpropenylacetate with dimethyl malonate. ${ }^{8} \mathrm{~A}$ subsequent study of the corresponding $\mathrm{Pd}(\mathrm{II})$ complexes has indicated that the good enantioselectivity achieved was a consequence of an efficient stereocontrol of the sulfur atom exerted by the exo-anomeric effect. ${ }^{9}$ In the case of phosphinite thioglycosides I metal complexes, where the exo-anomeric effect is not operative, good stereocontrol of the sulfur atom is also predicted taking into account the strong steric and stereoelectronic interactions of the substituent at sulfur and the endocyclic oxygen of the pyranose ring.<smiles>[R]C1OC(SP)C(OP)C([2H])C1[2H]</smiles>

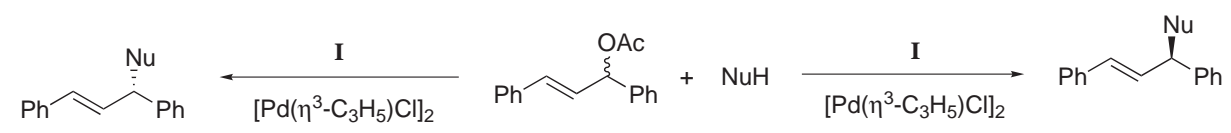

Scheme 1

SYNLETT 2005, No. 19, pp 2963-2967

Advanced online publication: 27.10.2005

DOI: 10.1055/s-2005-918963; Art ID: D20005ST

(c) Georg Thieme Verlag Stuttgart · New York 

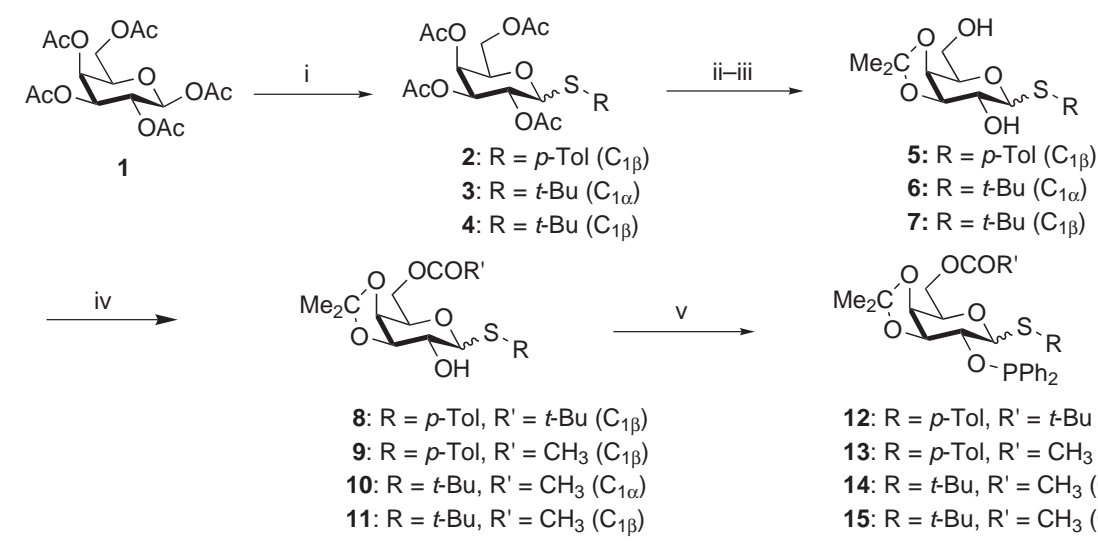

12: $\mathrm{R}=p$-Tol, $\mathrm{R}^{\prime}=t-\mathrm{Bu}\left(\mathrm{C}_{1 \beta}\right)$

13: $\mathrm{R}=p$-Tol, $\mathrm{R}^{\prime}=\mathrm{CH}_{3}\left(\mathrm{C}_{1 \beta}\right)$

14: $\mathrm{R}=t-\mathrm{Bu}, \mathrm{R}^{\prime}=\mathrm{CH}_{3}\left(\mathrm{C}_{1 \alpha}\right)$

15: $\mathrm{R}=t-\mathrm{Bu}, \mathrm{R}^{\prime}=\mathrm{CH}_{3}\left(\mathrm{C}_{1 \beta}\right)$

Scheme 2 Reagents and conditions: (i) $\mathrm{RSH}, \mathrm{BF}_{3} \cdot \mathrm{OEt}_{2}, \mathrm{CH}_{2} \mathrm{Cl}_{2}, 0^{\circ} \mathrm{C}$ or r.t. (80-95\%); (ii), MeONa, MeOH; (iii) DMP, CSA, acetone (75$80 \%$ for the 2 steps); (iv) R'COCl, pyridine or collidine, $\mathrm{CH}_{2} \mathrm{Cl}_{2},-78{ }^{\circ} \mathrm{C}$; (v) $\mathrm{PPh}_{2} \mathrm{Cl}_{1}, \mathrm{Et}_{3} \mathrm{~N}-\mathrm{THF}(70-80 \%)$.

Condensation of a thiol with galactose pentaacetate (1) in the presence of boron trifluoride afforded the corresponding thioglycosides 2-4 in high chemical yields (85-95\%, Scheme 2) ${ }^{10}$ Surprisingly, while this reaction is reported to be highly diastereoselective, leading to the 1,2-transthioglycoside, we have found that when tert-butanethiol was used as glycosyl acceptor the stereochemical outcome of the reaction was highly dependent on the reaction conditions. Condensation of tert-butanethiol with 1 at 0 ${ }^{\circ} \mathrm{C}$ afforded $\beta$-thioglycoside $\mathbf{4}$ as the main product in only one hour. In contrast, when conducted at room temperature the reaction was found to be thermodynamically controlled, affording $\alpha$ - and $\beta$-thioglycosides 3 and $\mathbf{4}$ in a $2: 1$ ratio. Fortunately, the two diastereoisomers 3 and $\mathbf{4}$ have high separation factors, allowing their preparation in high yields. A Zemplen deacetylation, followed by acidcatalyzed acetalation with 2,2-dimethoxypropane (DMP) afforded the 3,4-acetals 5-7 in 75-80\% yield. A regioselective acylation of primary alcohol with pivaloyl chloride in pyridine, or acetyl chloride in methylene chloride using collidine as base at $-78{ }^{\circ} \mathrm{C}$ afforded the monoalcohols 8 $\mathbf{1 1}$ in good yields. ${ }^{11}$ Finally, the installation of the phosphinite moiety has been carried out in a 1:1 mixture THF$\mathrm{Et}_{3} \mathrm{~N}$, using DMAP as catalyst in $80-90 \%$ yield. ${ }^{12}$ Thus, in only 5 high yielding steps the phosphinite thioglycosides 12-15 were obtained on a multigram scale (Scheme 2). ${ }^{13}$

The ability of the prepared phosphinite thioglycosides to act as chiral ligands in asymmetric catalysis was firstly assayed in the palladium-catalyzed allylic alkylation of 1,3-diphenylpropenylacetate (16) with dimethyl malonate. The reactions were conducted in methylene chloride using $3 \mathrm{~mol} \%$ of $\mathrm{Pd}$ and $4.3 \mathrm{~mol} \%$ of ligands, and the results are given in Table $1 .{ }^{14}$

As can be seen from Table 1, phosphinite thioglycosides are efficient precursors of the $\operatorname{Pd}(0)$ catalyst for the allylation of dimethyl malonate, as the desired product 17 was always obtained in good chemical yield. The enantioselectivity is highly dependent on the stereochemistry of the anomeric center and on the substituent of the sulfur. Significantly, while $\beta$-thioglycosides 12, 13 and 15 afforded the desired product with good yield and variable ee, $\alpha$-thioglycoside $\mathbf{1 4}$ led to the product in a very low ee (Table 1, entry 3). Aromatic thioglycosides 12 and 13 led to $17 \mathrm{~S}$ with the same moderate enantioselectivity around $60 \%$ ee (Table 1, entries 1 and 2). Bulkier alkyl thioglycosides, such as the tert-butyl thioglycoside $\mathbf{1 5}$, afforded the desired product $\mathbf{1 7 S}$ in up to $92 \%$ ee. Lowering the temperature has a beneficial effect on the enantioselectivity allowing the preparation of the $S$ isomer in an excellent $96 \%$ ee at $-20^{\circ} \mathrm{C}$. Owing to the success of these ligands in palladium-catalyzed asymmetric allylation of dimethyl malonate, they were assayed in the allylation of benzyl amine. The results of the allylic amination employing the same conditions as before are given in Table 2. Aromatic thioglycoside 13 (Table 2, entry 1) and axial thioglycoside 14 (Table 2, entry 2) afforded the allylated amine 18 with low ee, while the equatorial tert-butyl thioglycoside $\mathbf{1 5}$ afforded the product in good ee. As it can be seen from Table 2, the aminated product $18 R$ was obtained in an excellent $93 \%$ yield and good $90 \%$ ee at $0{ }^{\circ} \mathrm{C}$ (Table 2 , entry 4), lowering the temperature to $-20{ }^{\circ} \mathrm{C}$ afforded the $R$ isomer in $96 \%$ ee albeit in low yield (Table 2, entry 5).

As stated in the introduction, one of the drawbacks when using carbohydrates as chiral ligands in asymmetric catalysis is the difficulty to access to the other enantiomer. Accordingly, while D-glucose is the cheapest commercially available chiral starting material $(1.2 \mathrm{Eu} / \mathrm{mol})$, the corresponding enantiomer, L-glucose is prohibitively expensive $(8650 \mathrm{Eu} / \mathrm{mol})$, ruling out any possibility of using Lsugars even in catalytic amount. Using $\beta$-D-glucopyranoside as the chiral backbone, ${ }^{4}$ RajanBabu has demonstrated in the case of $\mathrm{Rh}(\mathrm{I})$-catalyzed hydrogenation, that the 3,4diphosphinite derivatives behave as pseudo-enantiomers to the 2,3-diphosphinite derivatives previously developed by Selke. ${ }^{15}$

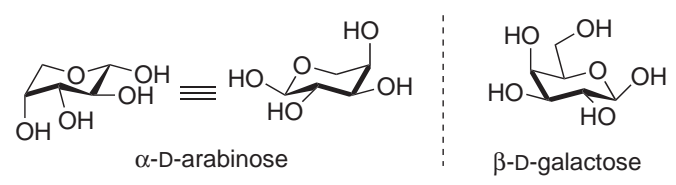

Figure 1 
Table 1 Pd-Catalyzed Allylic Alkylation of 1,3-Diphenylpropenyl Acetate 16 with Dimethyl Malonate Using Ligands 12-15
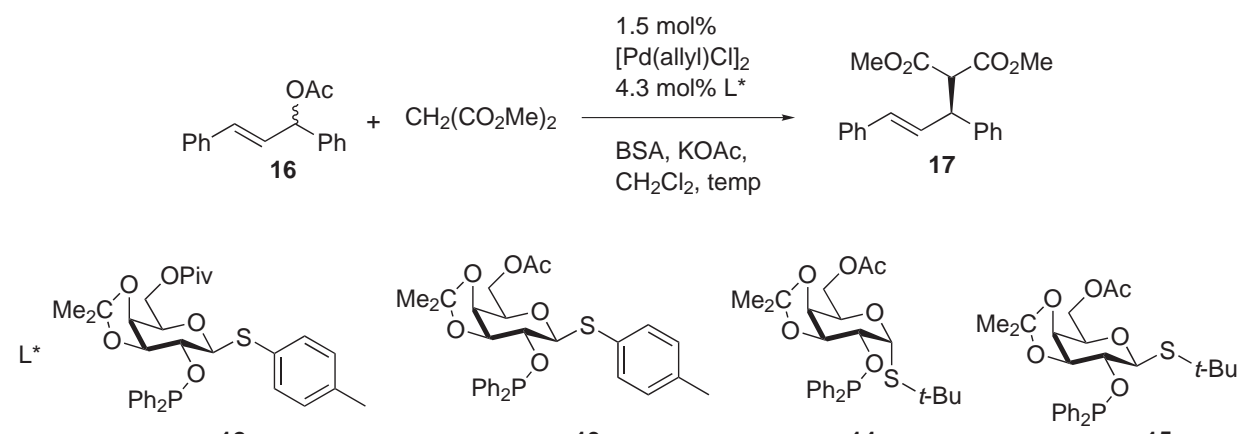

12

13

14

15

\begin{tabular}{lllll}
\hline Entry & Ligand $^{\mathrm{a}}$ & Temp $\left({ }^{\circ} \mathrm{C}\right)$ & ${\text { Yield }(\%)^{\mathrm{b}}}^{\text {ee }(\%)^{\mathrm{c}}}$ \\
\hline 1 & $\mathbf{1 2}$ & r.t. & 78 & 61 \\
2 & $\mathbf{1 3}$ & r.t. & 73 & 65 \\
3 & $\mathbf{1 4}$ & r.t. & 82 & 14 \\
4 & $\mathbf{1 5}$ & r.t. & 76 & 82 \\
5 & $\mathbf{1 5}$ & r.t. & 93 & $92^{\mathrm{d}}$ \\
6 & $\mathbf{1 5}$ & 0 & 72 & 94 \\
7 & $\mathbf{1 5}$ & -20 & 62 & 96 \\
\hline
\end{tabular}

${ }^{\text {a }}$ All reactions were conducted in $\mathrm{CH}_{2} \mathrm{Cl}_{2}$ using $4.3 \mathrm{~mol} \%$ of the ligand and $1.5 \mathrm{~mol} \%$ of $\left[\operatorname{PdCl}\left(\mathrm{C}_{3} \mathrm{H}_{5}\right)\right]_{2}$.

${ }^{\mathrm{b}}$ Isolated yield.

${ }^{c}$ Determined by HPLC using chiral column Chiralpack-AD.

${ }^{\mathrm{d}}$ Reagents: $8.6 \mathrm{~mol} \%$ of the ligand and $3 \mathrm{~mol} \%$ of $\left[\mathrm{PdCl}\left(\mathrm{C}_{3} \mathrm{H}_{5}\right)\right]_{2}$.

Nevertheless, this strategy cannot be applied in our case taking into account the nature of our ligands with two different heterodonating atoms, one of them at the anomeric position. In order to solve this problem, we have noticed that $\alpha$-D-arabinose, a cheap commercially available Dpentopyranose, which exists mainly in the ${ }^{1} \mathrm{C}_{4}$ conformation, is a quasi mirror image of $\beta$-D-galactose (Figure 1). ${ }^{16}$

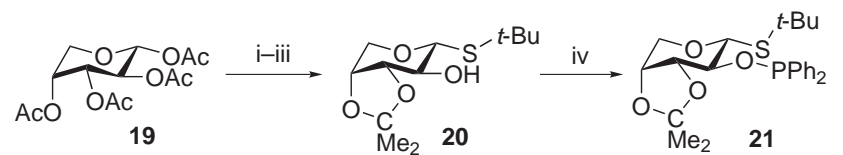

Scheme 3 Reagents and conditions: (i) $t$ - $\mathrm{BuSH}, \mathrm{BF}_{3} \cdot \mathrm{OEt}_{2}, \mathrm{CH}_{2} \mathrm{Cl}_{2}$, $0{ }^{\circ} \mathrm{C}$ (80-95\%); (ii) $\mathrm{MeONa}, \mathrm{MeOH}$; (iii) DMP, CSA, acetone (65\% for the 3 steps); (iv) $\mathrm{PPh}_{2} \mathrm{Cl}, \mathrm{Et}_{3} \mathrm{~N}-\mathrm{THF}$, DMAP (70-80\%).

We then wondered if phosphinite thioglycosides derived from arabinose could act as enantiomers to those derived from galactose. To do so, the synthesis of phosphinite thioarabinopyranoside related to $\mathbf{1 5}$ was planned. Starting from arabinose tetraacetate 19, the desired 2-phosphinite tert-butyl thioarabinopyranoside $\mathbf{2 1}$ was obtained in only four high yielding steps and on a multigram scale, (Scheme 3). The ligand 21 was then assayed in the $\mathrm{Pd}(0)$ catalyzed allylic substitution of 1,3-diphenyl propenylacetate 16. Using the same conditions as before $(3 \mathrm{~mol} \%$
Table 2 Pd-Catalyzed Allylic Amination of 1,3-Diphenylpropenyl Acetate 16 Using Ligands 13-15

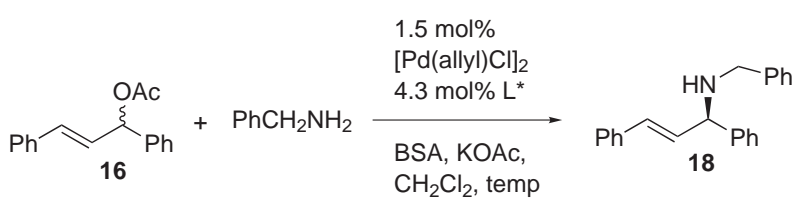

\begin{tabular}{|c|c|c|c|c|}
\hline Entry & Ligand $^{\mathrm{a}}$ & Temp $\left({ }^{\circ} \mathrm{C}\right)$ & Yield $(\%)^{\mathrm{b}}$ & ee $(\%)^{\mathrm{c}}$ \\
\hline 1 & 13 & r.t. & 89 & 46 \\
\hline 2 & 14 & r.t. & 71 & 32 \\
\hline 3 & 15 & r.t. & 76 & 86 \\
\hline 4 & 15 & 0 & 93 & 90 \\
\hline 5 & 15 & -20 & 29 & 96 \\
\hline
\end{tabular}

${ }^{a}$ All reactions were conducted in $\mathrm{CH}_{2} \mathrm{Cl}_{2}$ using $4.3 \mathrm{~mol} \%$ of the ligand and $1.5 \mathrm{~mol} \%$ of $\left[\mathrm{PdCl}\left(\mathrm{C}_{3} \mathrm{H}_{5}\right)\right]_{2}$.

$\mathrm{b}$ Isolated yield.

${ }^{\mathrm{c}}$ Determined by HPLC using chiral column Chiralpack-AD.

of palladium, $4.3 \mathrm{~mol} \%$ of $\mathbf{2 1}$ ) and dimethyl malonate as soft nucleophile afforded $17 R$, which is the opposite isomer to the one obtained with ligand $\mathbf{1 5}$, in $72 \%$ yield and an interesting $84 \%$ ee (Scheme 4). 


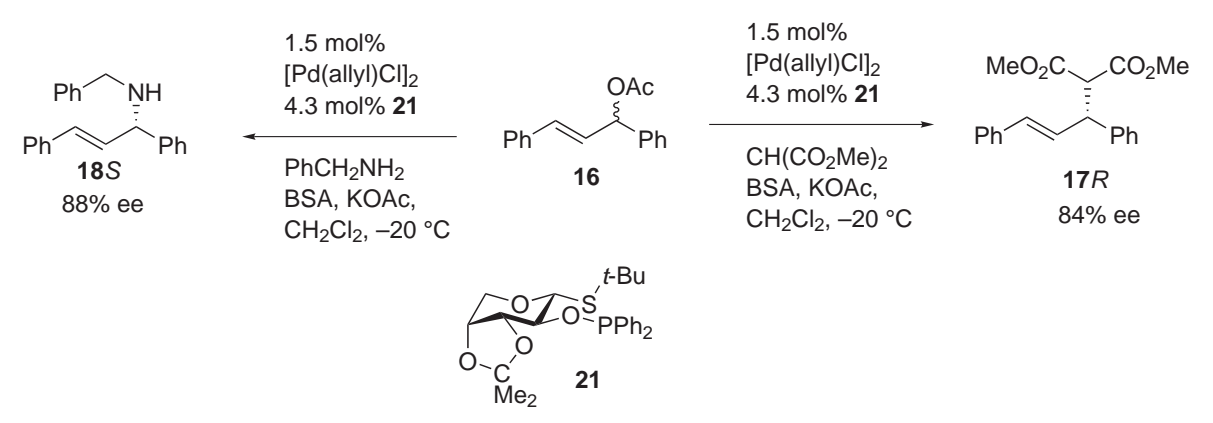

Scheme 4

When the nucleophile used was benzylamine, again the opposite isomer $18 S$ was obtained in an excellent $88 \%$ ee albeit in low yield (29\%), and in $78 \%$ ee and $67 \%$ yield at $0{ }^{\circ} \mathrm{C}$ (Scheme 4). Thus even though derived from natural D-sugars, ligands $\mathbf{1 5}$ and $\mathbf{2 1}$ behave as enantiomers in $\operatorname{Pd}(0)$-catalyzed asymmetric substitutions. The lower enantioselectivity observed with ligand $\mathbf{2 1}$ compared to 15 can be rationalized by a greater flexibility of the arabinopyranose vs. the galactopyranose rings.

The stereocontrol of the stereogenic sulfur metal center and its relation to the enantioselectivity of the substitution process was next probed. Thus, representative phosphinite thioglycosides $\mathrm{Pd}(\mathrm{II})$-complexes 22, 23 and $\mathbf{2 4}$ were synthesized and studied (Scheme 5).
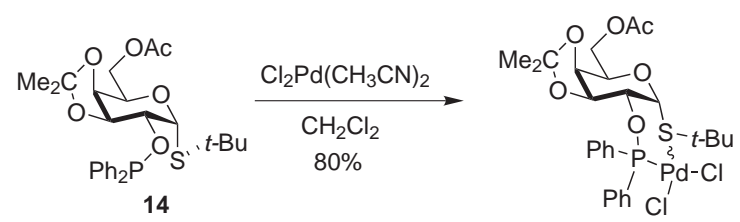

22 [2 isomers $(60: 40)]$
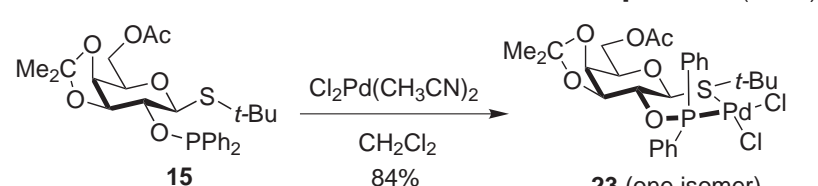

23 (one isomer)
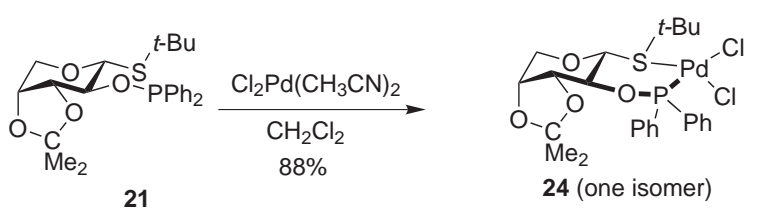

Scheme 5

Significantly, while two diastereoisomers were obtained in the case of $\mathbf{2 2}$ in a 2:3 ratio, only one isomer was obtained in the case of 23 and $24 .{ }^{1} \mathrm{H}$ and ${ }^{31} \mathrm{P}$ dynamic NMR studies of 23 from $-70{ }^{\circ} \mathrm{C}$ to $40{ }^{\circ} \mathrm{C}$ confirmed that a single isomer exists in solution, revealing an efficient control of the sulfur stereochemistry by the sugar residue and that the enantioselectivity achieved was intimately related to the stereocontrol of the sulfur atom.
In conclusion, the preliminary results reported in this work illustrate the high potential of phosphinite thioglycosides $\mathbf{I}$ in asymmetric catalysis and suggest their wider utility in other catalytic processes. The tuning of other parameters implemented in the synthetic design, such as the electronic character of the phosphinite moiety, and the conformation of the pyranose ring may certainly lead to more efficient catalysts. On the other hand the modular synthetic design developed will allow rapid attachment of these ligands to a solid support, while the hydrophilic nature of the sugar residue may allow the synthesis of water soluble catalysts, allowing their facile recovery and recycle. Work along these lines is currently under active investigation in our group.

\section{Acknowledgment}

We thank the Dirección General de Investigación Científica y Técnica (grant No. PB BQU2003-00937 and CTQ2004-01057) and La Fundación Ramón Areces for financial support.

\section{References}

(1) (a) Chiral Auxiliaries and Ligands in Asymmetric Synthesis; Seyden-Penne, J., Ed.; Wiley Interscience: New York, 1995. (b) Comprehensive Asymmetric Catalysis, Vol. 1-3; Jacobsen, E. N.; Pfaltz, A.; Yamamoto, H., Eds.; Springer: Berlin, 1999.

(2) (a) Dieguez, M.; Pàmies, O.; Claver, C. Chem. Rev. 2004, 104, 3189. (b) Steiborn, D.; Junicke, H. Chem. Rev. 2000, 100, 4283. (c) Rajanbabu, T. V.; Casalnuovo, A. L.; Ayers, T. A. In Advances in Catalytic Processes, Vol. 2; Doyle, M. P., Ed.; JAI Press: Greenwich CT, 1998, 1.

(3) (a) Casalnuovo, A. L.; RajanBabu, T. V.; Ayers, T. A.; Warren, T. H. J. Am. Chem. Soc. 1994, 116, 9869. (b) Selke, R.; Swarze, M.; Baudisch, H.; Grassert, I.; Michalik, M.; Oehme, G.; Stoll, N.; Costisella, B. J. Mol. Catal. 1993, 84, 223. (c) Dieguez, M.; Ruiz, A.; Claver, C. J. Org. Chem. 2002, 67, 3796. (d) Reetz, M. T.; Goosen, L. J.; Meiswinkel, A.; Paetzol, J.; Jensen, J. F. Org. Lett. 2003, 5,3099 .

(4) (a) Rajanbabu, T. V.; Ayers, T. A.; Casalnuovo, A. L. J. Am. Chem. Soc. 1994, 116, 4101. (b) Ayers, T. A.; RajanBabu, T. V. U. S. Patent 5510507, 1996.

(5) Evans, D. A.; Campos, K. R.; Tedrow, J. S.; Michael, F. E.; Gagné, M. R. J. Am. Chem. Soc. 2000, 122, 7905.

(6) This work has been presented in part in the ISOCS-XXI, Madrid, Spain, 4-9 July 2004. 
(7) (a) Molander, G.; Burke, J.; Carrol, P. J. J. Org. Chem. 2004, 69, 8062. (b) Mancheño, O. G.; Gomez Arrayas, R.; Carretero, J. C. J. Am. Chem. Soc. 2004, 126, 456. (c) Yan, Y. Y.; RajanBabu, T. V. Org. Lett. 2000, 2, 199.

(d) Albinati, A.; Pregosin, P. S.; Wick, K. Organometallics 1996, 15, 2419.

(8) Khiar, N.; Araújo, C. S.; Alvarez, E.; Fernández, I. Tetrahedron Lett. 2003, 44, 3401.

(9) Khiar, N.; Araújo, C. S.; Suárez, B.; Álvarez, E.; Fernández, I. Chem. Commun. 2004, 44, 714.

(10) (a) Ferrier, R. J.; Furneaux, R. H. Methods Carbohydr. Chem. 1980, 8, 251. (b) Khiar, N.; Martin-Lomas, M. J. Org. Chem. 1995, 60, 7017.

(11) Ishihara, K.; Kurihara, H.; Yamamoto, H. J. Org. Chem. 1993, 58, 3791.

(12) Yonehara, K.; Hashizume, T.; Mori, K.; Ohe, K.; Uemura, S. J. Org. Chem. 1999, 64, 5593.

(13) Compound 12: ${ }^{1} \mathrm{H} \mathrm{NMR}\left(500 \mathrm{MHz}, \mathrm{CDCl}_{3}\right): \delta=7.60-7.50$ $(\mathrm{m}, 4 \mathrm{H}), 7.38-7.31(\mathrm{~m}, 6 \mathrm{H}), 7.21(\mathrm{~d}, 2 \mathrm{H}, J=7.9 \mathrm{~Hz}), 7.02$ $(\mathrm{d}, 2 \mathrm{H}, J=8.0 \mathrm{~Hz}), 4.58(\mathrm{~d}, 1 \mathrm{H}, J=10.0 \mathrm{~Hz}), 4.35(\mathrm{dd}, 1$ $\mathrm{H}, J=4.5,11.7 \mathrm{~Hz}), 4.29(\mathrm{dd}, 1 \mathrm{H}, J=7.7,11.7 \mathrm{~Hz}), 4.23(\mathrm{t}$, $1 \mathrm{H}, J=5.9 \mathrm{~Hz}), 4.13(\mathrm{~d}, 1 \mathrm{H}, J=5.5 \mathrm{~Hz}), 4.02-3.93(\mathrm{~m}, 2$ H), 2.30 (s, $3 \mathrm{H}), 1.43$ (s, $3 \mathrm{H}), 1.29$ (s, $3 \mathrm{H}), 1.19(\mathrm{~s}, 9 \mathrm{H})$ ppm. ${ }^{13} \mathrm{C}$ NMR $\left(125 \mathrm{MHz}, \mathrm{CDCl}_{3}\right): \delta=178.3,137.7,132.4$, $131.1\left(\mathrm{~d}, J_{\mathrm{PC}}=11.8 \mathrm{~Hz}\right), 130.7\left(\mathrm{~d}, J_{\mathrm{PC}}=11.8 \mathrm{~Hz}\right), 129.3(\mathrm{~d}$, $\left.J_{\mathrm{PC}}=26.0 \mathrm{~Hz}\right), 128.1\left(\mathrm{~d}, J_{\mathrm{PC}}=6.8 \mathrm{~Hz}\right), 110.5,88.4(\mathrm{~d}$, $\left.J_{\mathrm{PC}}=4.1 \mathrm{~Hz}\right), 80.4\left(\mathrm{~d}, J_{\mathrm{PC}}=28.4 \mathrm{~Hz}\right), 79.1,74.0,73.7,63.7$, 38.7, 27.8, 27.1, 26.4, 21.2 ppm. ${ }^{31} \mathrm{P}$ NMR (121.4 MHz, $\left.\mathrm{CDCl}_{3}\right): \delta=119.5 \mathrm{ppm}$.

Compound 13: ${ }^{1} \mathrm{H}$ NMR $\left(500 \mathrm{MHz}, \mathrm{CDCl}_{3}\right): \delta=7.58-7.49$ $(\mathrm{m}, 4 \mathrm{H}), 7.36-7.32(\mathrm{~m}, 6 \mathrm{H}), 7.23(\mathrm{~d}, 2 \mathrm{H}, J=7.9 \mathrm{~Hz}), 7.03$ $(\mathrm{d}, 2 \mathrm{H}, J=7.9 \mathrm{~Hz}), 4.56(\mathrm{~d}, 1 \mathrm{H}, J=9.4 \mathrm{~Hz}), 4.33(\mathrm{~d}, 2 \mathrm{H}$, $J=6.1 \mathrm{~Hz}), 4.23(\mathrm{t}, 1 \mathrm{H}, J=5.9 \mathrm{~Hz}), 4.13(\mathrm{dd}, 1 \mathrm{H}$, $J=5.5,1.5 \mathrm{~Hz}), 4.03-3.91(\mathrm{~m}, 2 \mathrm{H}), 2.31(\mathrm{~s}, 3 \mathrm{H}), 2.07$ (s, 3 $\mathrm{H}), 1.41(\mathrm{~s}, 3 \mathrm{H}), 1.28(\mathrm{~s}, 3 \mathrm{H}) \mathrm{ppm} .{ }^{13} \mathrm{C}$ NMR $(125 \mathrm{MHz}$, $\left.\mathrm{CDCl}_{3}\right): \delta=170.8,142.6\left(\mathrm{~d}, J_{\mathrm{PC}}=18.5 \mathrm{~Hz}\right), 141.9(\mathrm{~d}$, $\left.J_{\mathrm{PC}}=15.4 \mathrm{~Hz}\right), 137.7,132.6,130.9\left(\mathrm{~d}, J_{\mathrm{PC}}=21.8 \mathrm{~Hz}\right), 130.8$ $\left(\mathrm{d}, J_{\mathrm{PC}}=21.8 \mathrm{~Hz}\right), 130.2,129.3\left(\mathrm{~d}, J_{\mathrm{PC}}=30.2 \mathrm{~Hz}\right), 128.1(\mathrm{~d}$, $\left.J_{\mathrm{PC}}=6.9 \mathrm{~Hz}\right), 110.6,87.9\left(\mathrm{~d}, J_{\mathrm{PC}}=4.2 \mathrm{~Hz}\right), 80.0(\mathrm{~d}$, $\left.J_{\mathrm{PC}}=18.4 \mathrm{~Hz}\right), 79.1,73.9,73.6,63.8,27.7,26.4,21.1,20.8$ ppm. ${ }^{31} \mathrm{P}$ NMR (121.4 MHz, $\left.\mathrm{CDCl}_{3}\right): \delta=119.4 \mathrm{ppm}$. Compound 14: ${ }^{1} \mathrm{H}$ NMR $\left(500 \mathrm{MHz}, \mathrm{CDCl}_{3}\right): \delta=7.57-7.50$ $(\mathrm{m}, 4 \mathrm{H}), 7.35-7.32(\mathrm{~m}, 6 \mathrm{H}), 5.56(\mathrm{~d}, 1 \mathrm{H}, J=5.1 \mathrm{~Hz}), 4.70$ $4.67(\mathrm{~m}, 1 \mathrm{H}), 4.34-4.11(\mathrm{~m}, 5 \mathrm{H}), 2.02(\mathrm{~s}, 3 \mathrm{H}), 1.41(\mathrm{~s}, 3$ $\mathrm{H}), 1.30(\mathrm{~s}, 12 \mathrm{H}) \mathrm{ppm} .{ }^{13} \mathrm{C} \mathrm{NMR}\left(125 \mathrm{MHz}, \mathrm{CDCl}_{3}\right): \delta=$ $170.7,141.8\left(\mathrm{~d}, J_{\mathrm{PC}}=19.4 \mathrm{~Hz}\right), 141.7\left(\mathrm{~d}, J_{\mathrm{PC}}=16.0 \mathrm{~Hz}\right)$, $130.9\left(\mathrm{~d}, J_{\mathrm{PC}}=21.8 \mathrm{~Hz}\right), 130.7\left(\mathrm{~d}, J_{\mathrm{PC}}=21.7 \mathrm{~Hz}\right), 129.3(\mathrm{~d}$,
$\left.J_{\mathrm{PC}}=2.7 \mathrm{~Hz}\right), 128.2\left(\mathrm{~d}, J_{\mathrm{PC}}=7.0 \mathrm{~Hz}\right), 128.1\left(\mathrm{~d}, J_{\mathrm{PC}}=7.0\right.$ $\mathrm{Hz}), 109.7,81.3\left(\mathrm{~d}, J_{\mathrm{PC}}=5.6 \mathrm{~Hz}\right), 77.8\left(\mathrm{~d}, J_{\mathrm{PC}}=18.8 \mathrm{~Hz}\right)$, $75.6\left(\mathrm{~d}, J_{\mathrm{PC}}=5.0 \mathrm{~Hz}\right), 73.8,66.6,63.5,43.8,31.3,27.9$, 26.3, 20.8 ppm. ${ }^{31} \mathrm{P}$ NMR (121.4 MHz, $\left.\mathrm{CDCl}_{3}\right): \delta=117.5$ ppm.

Compound 15: ${ }^{1} \mathrm{H}$ NMR $\left(500 \mathrm{MHz}, \mathrm{CDCl}_{3}\right): \delta=7.56-7.47$ $(\mathrm{m}, 4 \mathrm{H}), 7.34-7.29(\mathrm{~m}, 6 \mathrm{H}), 4.51(\mathrm{~d}, 1 \mathrm{H}, J=9.5 \mathrm{~Hz}), 4.33$ $4.26(\mathrm{~m}, 3 \mathrm{H}), 4.15(\mathrm{dd}, 1 \mathrm{H}, J=1.8,5.6 \mathrm{~Hz}), 3.96-3.88(\mathrm{~m}$, $2 \mathrm{H}), 2.03(\mathrm{~s}, 3 \mathrm{H}), 1.42(\mathrm{~s}, 3 \mathrm{H}), 1.29(\mathrm{~s}, 3 \mathrm{H}), 1.22(\mathrm{~s}, 9 \mathrm{H})$ ppm. ${ }^{13} \mathrm{C} \mathrm{NMR}\left(125 \mathrm{MHz}, \mathrm{CDCl}_{3}\right): \delta=170.8,142.9(\mathrm{~d}$, $\left.J_{\mathrm{PC}}=18.4 \mathrm{~Hz}\right), 142.1\left(\mathrm{~d}, J_{\mathrm{PC}}=15.2 \mathrm{~Hz}\right), 131.3\left(\mathrm{~d}, J_{\mathrm{PC}}=22.1\right.$ $\mathrm{Hz}), 130.5\left(\mathrm{~d}, J_{\mathrm{PC}}=21.3 \mathrm{~Hz}\right), 129.0\left(\mathrm{~d}, J_{\mathrm{PC}}=32.5 \mathrm{~Hz}\right), 128.0$ $\left(\mathrm{d}, J_{\mathrm{PC}}=6.4 \mathrm{~Hz}\right), 127.9\left(\mathrm{~d}, J_{\mathrm{PC}}=7.2 \mathrm{~Hz}\right), 110.5,83.1(\mathrm{~d}$, $\left.J_{\mathrm{PC}}=3.3 \mathrm{~Hz}\right), 80.6\left(\mathrm{~d}, J_{\mathrm{PC}}=18.7 \mathrm{~Hz}\right), 79.3\left(\mathrm{~d}, J_{\mathrm{PC}}=2.7 \mathrm{~Hz}\right)$, 73.6 (2 C), 63.9, 44.1, 31.3, 27.7, 26.4, 20.8 ppm. ${ }^{31} \mathrm{P}$ NMR $\left(121.4 \mathrm{MHz}, \mathrm{CDCl}_{3}\right): \delta=119.8 \mathrm{ppm}$.

Compound 21: ${ }^{1} \mathrm{H}$ NMR $\left(500 \mathrm{MHz}, \mathrm{CDCl}_{3}\right): \delta=7.54-7.46$ $(\mathrm{m}, 4 \mathrm{H}), 7.33-7.29(\mathrm{~m}, 6 \mathrm{H}), 4.76(\mathrm{~d}, 1 \mathrm{H}, J=6.9 \mathrm{~Hz}), 4.28-$ $4.26(\mathrm{~m}, 1 \mathrm{H}), 4.22(\mathrm{t}, 1 \mathrm{H}, J=5.7 \mathrm{~Hz}), 4.10-4.01(\mathrm{~m}, 1 \mathrm{H})$, $3.70(\mathrm{dd}, 1 \mathrm{H}, J=4.4,12.7 \mathrm{~Hz}), 1.47(\mathrm{~s}, 3 \mathrm{H}), 1.30(\mathrm{~s}, 3 \mathrm{H})$, 1.19 (s, $9 \mathrm{H}$ ) ppm. ${ }^{13} \mathrm{C} \mathrm{NMR}\left(125 \mathrm{MHz}, \mathrm{CDCl}_{3}\right): \delta=131.2$ $\left(\mathrm{d}, J_{\mathrm{PC}}=22.1 \mathrm{~Hz}\right), 130.5\left(\mathrm{~d}, J_{\mathrm{PC}}=21.4 \mathrm{~Hz}\right), 129.1\left(\mathrm{~d}, J_{\mathrm{PC}}=\right.$ $31.7 \mathrm{~Hz}), 128.1\left(\mathrm{~d}, J_{\mathrm{PC}}=5.9 \mathrm{~Hz}\right), 128.0\left(\mathrm{~d}, J_{\mathrm{PC}}=6.7 \mathrm{~Hz}\right)$, $110.1,84.5,82.6\left(\mathrm{~d}, J_{\mathrm{PC}}=4.2 \mathrm{~Hz}\right), 80.3\left(\mathrm{~d}, J_{\mathrm{PC}}=19.2 \mathrm{~Hz}\right)$, 72.2, 63.2, 44.0, 31.3, 27.8, 26.3 ppm. ${ }^{31} \mathrm{P}$ NMR (121.4 $\left.\mathrm{MHz}, \mathrm{CDCl}_{3}\right): \delta=118.6 \mathrm{ppm}$.

(14) Typical Procedure.

To a solution of the ligand $(4.3 \mathrm{~mol} \%)$ in dry deoxygenated $\mathrm{CH}_{2} \mathrm{Cl}_{2}(0.5 \mathrm{~mL}),\left[\mathrm{PdCl}\left(\mathrm{C}_{3} \mathrm{H}_{5}\right)\right]_{2}(1.5 \mathrm{~mol} \%)$ was added under argon. The reaction mixture was stirred for $1 \mathrm{~h}$ at r.t., then a catalytic amount of KOAc $(0.5 \mathrm{mg})$ was added, followed by BSA ( 3 mol equiv) and a solution of 1,3diphenyl-2-propenyl acetate (16,1 mol equiv) in dry deoxygenated $\mathrm{CH}_{2} \mathrm{Cl}_{2}(0.7 \mathrm{~mL})$. The temperature was then adjusted to the desired one (see Table 1) and dimethyl malonate (3 equiv) was added. Once the reaction finished as judged by TLC, the solvent was evaporated and the residue purified by column chromatography, affording the desired product $\mathbf{1 7}$ as a viscous oil, which solidify on standing. The ee was determined by chiral HPLC using a Chiralpack AD column $\left(1 \mathrm{~mL} / \mathrm{min}, i\right.$-PrOH-hexane, 5:95, $\left.30{ }^{\circ} \mathrm{C}\right)$. Retention times: $(R)-17: t_{\mathrm{R}}=14.2 \mathrm{~min},(S)-17: t_{\mathrm{R}}=19.5 \mathrm{~min}$.

(15) (a) Selke, R. React. Kinet. Catal. Lett. 1980, 14, 463. (b) Selke, R. J. Organomet. Chem. 1989, 370, 249.

(16) Kunz, H.; Pfrengle, W.; Sager, W. Tetrahedron Lett. 1989, 30, 4109. 